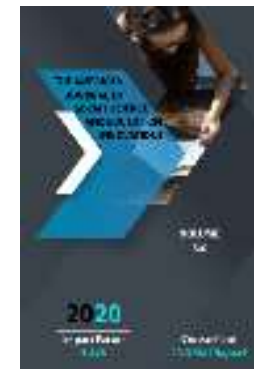

Journal Website: http://usajournalshub.c om/index,php/tajssei

Copyright: Original content from this work may be used under the terms of the creative commons attributes 4.0 licence.

\section{Considering Psychological And Pedagogical Characteristics Of Young Learners In Improving Professional Competence Of Primary School English Teachers}

Svetlana Sergeevna Khan

M.Ed, Exeter University, UK National Innovation Centre At Uzbekistan State World Languages University, Uzbekistan Head Of Quality Improvement And Material Design Department, Uzbekistan

\title{
ABSTRACT
}

The article looks into the importance of taking into account psychological, pedagogical and age characteristics of children of primary school age was caused by the world phenomena of introducing English at younger ages. One of the main aspects of creating necessary conditions for ensuring the effectiveness of the in-service teacher training courses is considering the level of language and methodological training of English teachers and bringing the goals, objectives and content of the inservice courses in line with the goals and objectives of the education. Teachers who teach English in primary schools, along with general pedagogy, theory and methods of teaching English, need to know the specifics of working with children of primary school age, including psychological and age characteristics.

The process of teaching English has changed over the past decades, affecting both teachers and students. This influence is especially noticeable when children start learning a foreign language at the primary school level, where not only the basics of a foreign language are laid, but also the foundation of the child's educational system. The role of the teacher in the process of teaching primary school children is very important, as it should cover many aspects, including: designing children's activities in the classroom that maximize their use of English; selecting language tasks that will ensure linguistic progress; maintaining motivation and a positive attitude of learners to learning a foreign language.

\section{KEYWORDS}

psychological, pedagogical and age characteristics of children of primary school age, the role of the teacher, human cognitive system, integrated approach to language learning. 


\section{INTRODUCTION}

Friendly The need to study specific features of teaching English for teachers working in primary schools, taking into account psychological, pedagogical and age characteristics of children of primary school age was caused by the world phenomena of introducing English at younger ages. One of the main aspects of creating necessary conditions for ensuring the effectiveness of the in-service teacher training courses is taking into account the level of language and methodological training of English teachers and bringing the goals, objectives and content of the in-service courses in line with the goals and objectives of the education.

Theoretical knowledge of pedagogy and methods of teaching foreign languages in primary schools is important and the teacher should be guided by them in their work. However, in reality, as numerous studies around the world indicate, there is a huge gap between theory and practice, and young novice teachers experience difficulties and complain that their studies at the university did not prepare them for the reality they meet at school. (Allen, 2009; Cochran-Smiff, 2005; Sandlin, Young and Karge, 1992).

Providing assistance to a novice teacher in attempts to apply theoretical knowledge in practice is an important task for the educational system. Compared to the study of general pedagogy, understanding the focusoriented area of pedagogy will be of more benefit to the teacher and help the teacher apply the theory in practice. Shulman (1986), the founder of the concept of pedagogical content knowledge supports scientists, methodologists and teacher practitioners who develop the principles of integration of knowledge in the content and pedagogy.

Teachers who teach English in primary schools, along with general pedagogy, theory and methods of teaching English, need to know the specifics of working with children of primary school age, including psychological and age characteristics. Learning English should be considered as part of the overall development of the child, so the educational material and teaching methods should correspond to the stage of development of the child. Brewster and Ellis (2004: 5) give the following classification: psychological readiness, linguistic and cultural readiness. The child cannot learn what he is not ready for, and what he cannot understand. For example, learning grammar at an early stage is not effective because the child cannot learn abstract concepts.

\section{The importance of developing learning strategies for primary school children}

Well known scholars claim that language learning by children of primary school age is directly dependent on the fact that children are constantly in the learning environment. Therefore, those teachers who support an integrated approach to language learning advocate full use of the learning environment and context in which the child lives every day, including the cultural and socio-cultural context. Accordingly, the characteristics of a successful learner will be influenced by the learning environment and understanding of how the child learns. As a result, the development of learning skills is a very important factor in the education of primary school children. (Ellis, 1991) 
The process of teaching English has changed over the past decades, affecting both teachers and students. This influence is especially noticeable when children start learning a foreign language at the primary school level, where not only the basics of a foreign language are laid, but also the foundation of the child's educational system. The role of the teacher in the process of teaching primary school children is extremely important, as it should cover many aspects, including: designing children's activities in the classroom that maximize children's use of English; selecting language tasks that will ensure linguistic progress; maintaining motivation and a positive attitude of learners to learning a foreign language.

One of the main principles of teaching foreign languages in primary school is acceptance of the child as a single integral world. Primary school teachers should not only be foreign language specialists, but also good psychologists to create a positive language environment and teach children to learn. Modern teacher training courses are based not only on learning the language and its features, but also on intensive study of pedagogy, sociology and psychology. Thus, English teachers in primary schools should not only teach what English is and how it works, but also create an environment in which learners can apply their knowledge and skills in communicating in a foreign language.

The development of various types of new technologies and new theories of education is gradually changing the way we think about learning. These changes create new challenges in the world of schools and education. Over the years, linguistic and educational research has led to new theories about how language is learned. This has led to the development of different approaches to learning that favor different aspects of learning and the human cognitive system.

Each learner has different abilities in learning a foreign language. Some easily grasp it and study it with ease and pleasure, while others experience difficulties that can lead to frustration and lack of interest in the language being studied. This leads to the question of what an English teacher can and should do to create the prerequisites for successful learning. It is widely recognized that teachers who teach young learners must not only teach, but also create a positive learning environment for learners which can help to boost and sustain learner's motivation.

\section{VARIOUS ROLES OF A TEACHER}

Before looking at various roles of a teacher, it is necessary to clarify what we mean by the word "role". The Oxford Advanced Learners Dictionary gives the following definition: "A function or position that someone has or should have in an organization, in society, or in a relationship." Whether we realize it or not, we perform different roles in many situations on a daily basis and face different expectations. In this way, we can play various roles: for example, a teacher can be a loving mother at home and a director at school. These roles differ in the way they are chosen: she can choose whether she wants to act as school director, but her own children will always see her as a mother. She doesn't have to be the school director, but by taking on this role, she makes certain commitments and the staff at school expects her to act accordingly.

Despite the claims of some scientists and practitioners that the role of the teacher has not changed at all and remains the same as it was at all times, we must recognize that the role of the English teacher in the modern educational process is undergoing and should 
undergo radical changes. We are moving from traditional methods and grammatical translations to new methods that put the needs, beliefs, emotions, and motivations of learners at the center of attention. The shift towards a person-centered approach considers language as a means of communication. The importance of the communication aspect is fundamental. It is clear that students now need to learn not only the rules of grammar, but above all, they must be able to understand and be understood. Education First English Proficiency index (EF EPI, 2017) ranked 80 countries by English proficiency. Of these countries, $56 \%$ are rated as low or very low, $18 \%$ as moderate, and only $26 \%$ as high or very high. What could be the reason for these poor English proficiency results around the world? Part of the reason for this slow progress may be the traditional focus on reading and translating as well as learning and memorizing grammatical rules. In the traditional classroom, the role of the teacher was mainly to explain language phenomena and control the comprehension of these models. In a contemporary English class, the requirements for a teacher are much higher than in a traditional class. (Prodromou 1991) In today's dynamic classroom, the teacher performs many roles with different goals. We can look at some of them.

\section{CONTROLLING}

The most commonly accepted idea of a teacher's role may be a perfectly organized classroom in which everything is under the teacher's control. (Harmer 2007: 108). Although this style is more suited to the traditional and outdated, it still finds support among many teachers and students. However, despite the fact that a democratic style is more preferable in the modern language class, even a teacher with a democratic learning style can sometimes act as a teachercontroller, especially when explaining new material, checking homework or conducting tests.

\section{ASSESSMENT}

The teacher conducts assessment constantly, both during regular lessons and during various types of tests. Teachers should evaluate their learners by correcting them and giving feedback, which contributes to the development of self-education skills. (Harmer, 2007: 109)

Another very important role of the teacher is the role of the organizer of the educational process. Good organization is a key factor when planning a curriculum, lesson, or just a specific task and helps discipline students.

In addition, the teacher acts as a consultant, helping students when necessary. The teacher provides additional information or just talks to them, providing an opportunity in language practice. (Harmer, 2007: 109)

Participation in the learning process to improve the effectiveness of teaching, the teacher sometimes needs to act with learners at the same level as everyone else, that is, to become an equal participant in the lesson, for example, a participant in a role-playing game, dramatization, or debate. The teacher will not only get an idea of how learners develop their language skills, but also give them the opportunity to get closer to learners and interact with them on a different level.

\section{RESEARCH}

A role that is not directly related to teacher behavior in the classroom, but is very important for professional growth, is that of a research scientist. The teacher analyzes the 
learning process, observes what is happening in the classroom, what works and what does not, and makes appropriate conclusions that determine further work. (Harmer, 2007: 109)

\section{MODEL}

Another very important role is that of a role model that goes beyond the classroom, but has an impact on children throughout their lives. Honesty, or fairness, for example, is learned not only from parents, but also from teachers at school. Therefore, teachers must be fully aware that their behavior in general has a huge impact on the personal development of their learners. A good teacher should be able to adapt the curriculum and materials to the needs, needs and interests of learners who are direct and active participants in the learning process. In this process, the role of the teacher changes radically. In the modern model, the teacher assumes the role of facilitator and organizer of the educational process, providing learners with the opportunity to learn and communicate in the language.

A number of scholars claim that children do not come to a foreign language lesson "empty-handed". They bring with them an already well-developed system of instincts, skills, and characteristics that help them master a foreign language. We, as educators, should help them understand them and use them as much as possible in the learning process.

For example, children, even at the very beginning of their education, have the following skills:

They are very good at understanding and interpreting the meaning of what is said, even if they don't understand the meaning of all the words;
Are able to creatively and effectively use the minimum language stock;

Are able to enjoy the learning process and create appropriate conditions;

Have a well-developed imagination;

Very fond of reasoning and talking. (adapted from "Teaching Young Learners" by Paula de Nagy)

\section{CONCLUSION}

In conclusion, it should be stressed that teachers who teach English in primary schools, along with general pedagogy, theory and methods of teaching English, need to know and address the specifics of working with children of primary school age, including psychological and age characteristics. Thus the role of teachers is of higher importance, as it is widely recognized that teachers who teach young learners must not only teach, but also create a positive learning environment for learners and prerequisites for successful learning.

\section{REFERENCE}

1. Allen, J. M. (2009). Valuing practice over theory: How beginning teachers re-orient their practice in the transition from the university to the workplace. Teaching and teacher education, 25(5), 647-654. http://dx.doi.org/10.1016/j.tate.2008.11.011

2. Brewster, J., Ellis, G. \& Girard, D. (2004). The Primary English Teacher's Guide. London: Penguin

3. Cochran-Smith, M. (2005). Studying teacher education: what we know and need to know. Journal of Teacher Education, 56, 301-307 http://dx.doi.org/10.1177/002248710528011 6 
4. Ellis, G. (1991). Second language acquisition and language pedagogy. Clevedon, UK: Multilingual Matters

5. Harmer, J. 2007. The Practice of English Language Teaching. Pearson Education Ltd.

6. Prodromou, L. 1991. The Good Language Teacher. English Teaching Forum

7. Sandlin, R. A., Young, B. L., \& Karge, B. D. (1992). Regularly and alternatively credentialed beginning teachers: Comparison and contrast of their development. Action in Teacher Education, 14(4), 16-23. http://dx.doi.org/10.1080/01626620.1993.1 0463137

8. Shulman, L. S. (1986). Those who understand: Knowledge growth in teaching. Educational Researcher, 15, 1-14. 